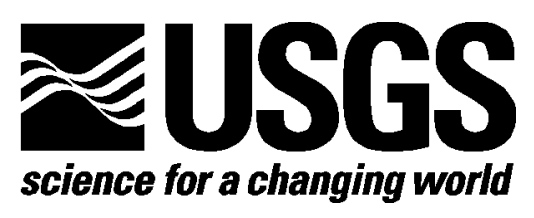

\title{
Digital Soils Survey Map of the Patagonia Mountains, Arizona
}

By Laura Norman 1 , Craig Wissler ${ }^{2}$, D. Phillip Guertin 2 , and Floyd Gray ${ }^{1}$

Open-File Report 02-324

2002

This report is preliminary and has not been reviewed for conformity with U.S. Geological Survey editorial standards or with the North American Stratigraphic Code. Any use of trade, product or firm names is for descriptive purposes only and does not imply endorsement by the U.S. Government.

\section{U. S. DEPARTMENT OF THE INTERIOR}

\section{U.S. GEOLOGICAL SURVEY}

1U.S. Geological Survey, Tucson, Arizona

${ }^{2}$ The University of Arizona, Tucson, Arizona 


\section{Table of Contents}

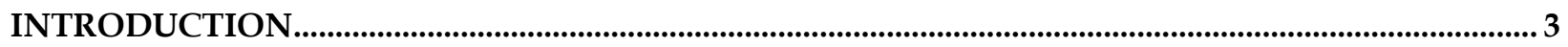

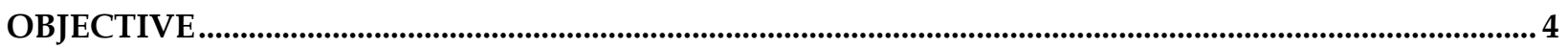

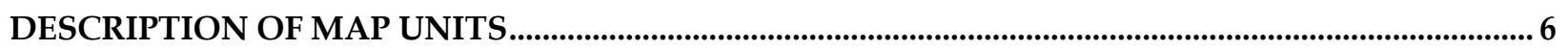

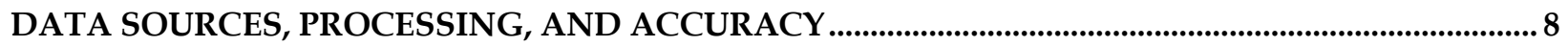

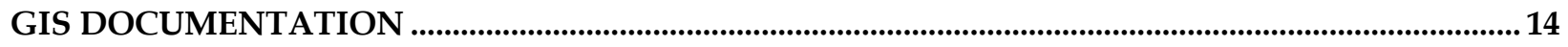

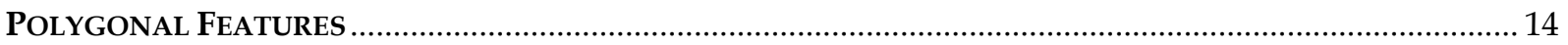

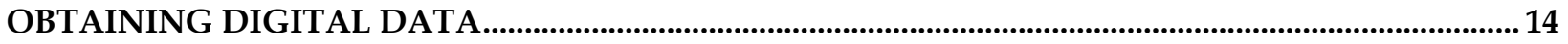

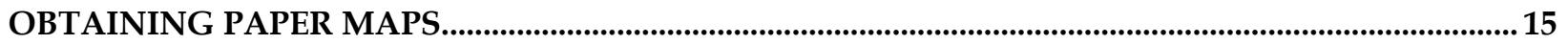

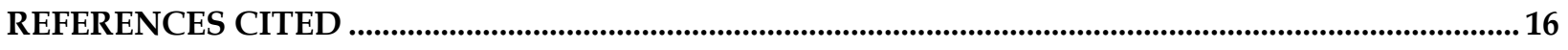

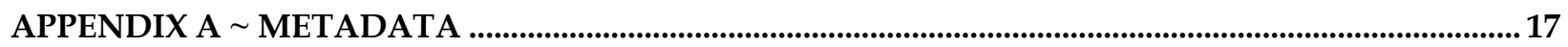

\section{List of Figures}

FigURE 1: INDEX MAP SHOWING THE GEOGRAPHIC EXTENT OF THE PATAGONIA MOUNTAINS STUDY AREA........... 5

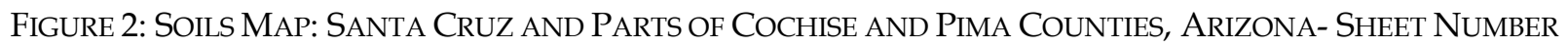

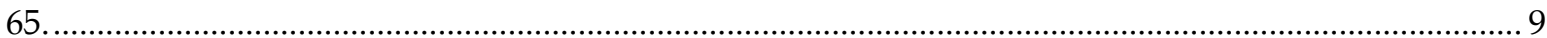

FIGURE 3: PICTURE OF ERDAS IMAGINE GEORECTIFICATION PROCESS......................................................... 10

FIGURE 4: CAMPGROUND AREA OF AERIAL PHOTO DEPICTING ERROR FROM OVERLAIN VECTOR COVERAGE OF

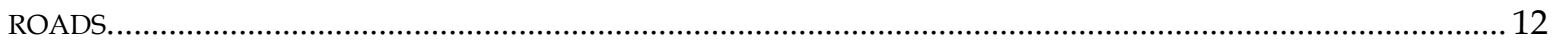

FiguRE 5: THIS DigiTAL SOILS SURVEY MAP OF THE PATAGONIA MOUNTAINS, ARIZONA IS AVAILABLE AT A 40 X33 INCH MAP SIZE JPEG IN THIS DIGITAL RELEASE. .............................................................................. 13

\section{List of Tables}

TABLE 1: SYMBOLS, SOILS' ASSOCIATION AND USDA SURFACE TEXTURES IN THE PATAGONIA SOILS MAP (U.S. DEPARTMENT OF AGRICULTURE: SOIL CONSERVATION SERVICE AND FOREST SERVICE IN COOPERATION WITH ARIZONA AGRICULTURAL EXPERIMENT STATION, 1979)................................................................... 6

TABle 2: SLOPE ATtRIBUTES (U.S. DEPARTMENT OF AGRICUlturE: SOIL CONSERVATION SERVICE AND FOREST SERVICE IN COOPERATION WITH ARIZONA AGRICULTURAL EXPERIMENT STATION, 1979)........................... 8

TABLE 3: DESCRIPTIONS AND DATA TYPE OF THE USER DEFINED ITEMS IDENTIFYING POLYGON FEATURES (SYMBOL, SLOPE AND ERODIBILITY). 


\section{Introduction}

The Patagonia - southern Santa Rita Mountains area, located in Southeastern Arizona (fig. 1), is approximately 60 miles SE of Tucson and at its northern edge, 10 miles North of the US Mexico border. The area was mined intermittently from the 1600 's to the mid-1960's primarily for silver, lead, copper, and zinc.

The U. S. Geological Survey in cooperation with the U. S. Department of Agriculture Forest Service is conducting a combined Preliminary Assessment (PA)/Site Inspection (SI) of small watersheds that have been potentially impaired by historical mining activities in southern Arizona. Mineral deposit geology, climate, weathering processes, faults, and fractures are factors affecting environmental conditions existing in the area (Gray and others, 2000). The project integrates new and existing geologic, geophysical, and geochemical data and imagery to provide visualizations of the Sonoita Creek basin and adjacent Patagonia Mountains. Emphasis is placed upon development of baseline information, a better knowledge of these aquifer systems, and the understanding of the distribution of metals related to mineralization and their fate in the surface and subsurface environments. The objective is to provide information useful for defining areas of significant environmental impact from erosion processes and to provide some insight on the most practical remediation strategies to be employed. The data provided in the digital soils map presented within this paper, is one of several essential components supporting the overall environmental assessment of the area. Digital data models, like the ones presented in Brady (2000), Gray and others (2000), and Brady and others (2001) require accurate representation of soil material in the area as input. The Universal Soil Loss Equation (USLE) (Wischmeier 1976, Wischmeier and Smith, 1978) and the Spatially Explicit Delivery MODel (SEDMOD) (Fraser, 1999) were chosen to assist in characterization of potential point and nonpoint source material yield within selected drainage systems.

An integrated analysis using a Geographic Information Systems (GIS)-based platform was implemented to examine three-dimensional visualizations of transport mechanisms within the headwaters of the Patagonia watersheds that ultimately drain to the Sonoita Creek. Sediment transport characteristics were modeled with emphasis on development of background information in this historically mined area, as well as the distribution of metals in the sediment and their destiny in the defined watersheds. 


\section{Objective}

Historical analog soils data were automated to create a high resolution digital soils survey map of the Patagonia Mountains, Arizona. Preexisting, high-resolution soils data could not be found in digital form. The most accurate soil information for the study area was in hard copy. This was available as 1:20,000 scale maps in the "Soil Survey of Santa Cruz and Parts of Cochise and Pima Counties, Arizona" (USDA, SCS \& FS, 1979), a product of the U.S. Department of Agriculture's Soil Conservation Service and Forest Service in cooperation with the Arizona Agricultural Experiment Station. These maps were created according to the site conditions in 1971. Aerial photography was used to accurately map polygonal soil types according to field tests. The 1979 soil maps were automated for incorporation into the hydrologic modeling within a GIS.

The resulting digital database can be queried in many ways to produce a variety of soils maps, utilizing attributed polygons. Digital base map data files (topography, roads, towns, rivers and lakes, etc.) are not included. They may be obtained from a variety of commercial and government sources. The soil coverage is not meant to be used or displayed at any scale larger than 1:20,000 (e.g., 1:10,000).

The mapped area is located in Southeast Arizona (fig. 1). This open-file report describes the soil map units, the methods used to convert the soils map data into a digital format, the ArcInfo GIS file structures, and methods for downloading the digital files from the U.S. Geological Survey public access World Wide Web site on the Internet. Karen Bolm reviewed manuscript and digital files. 


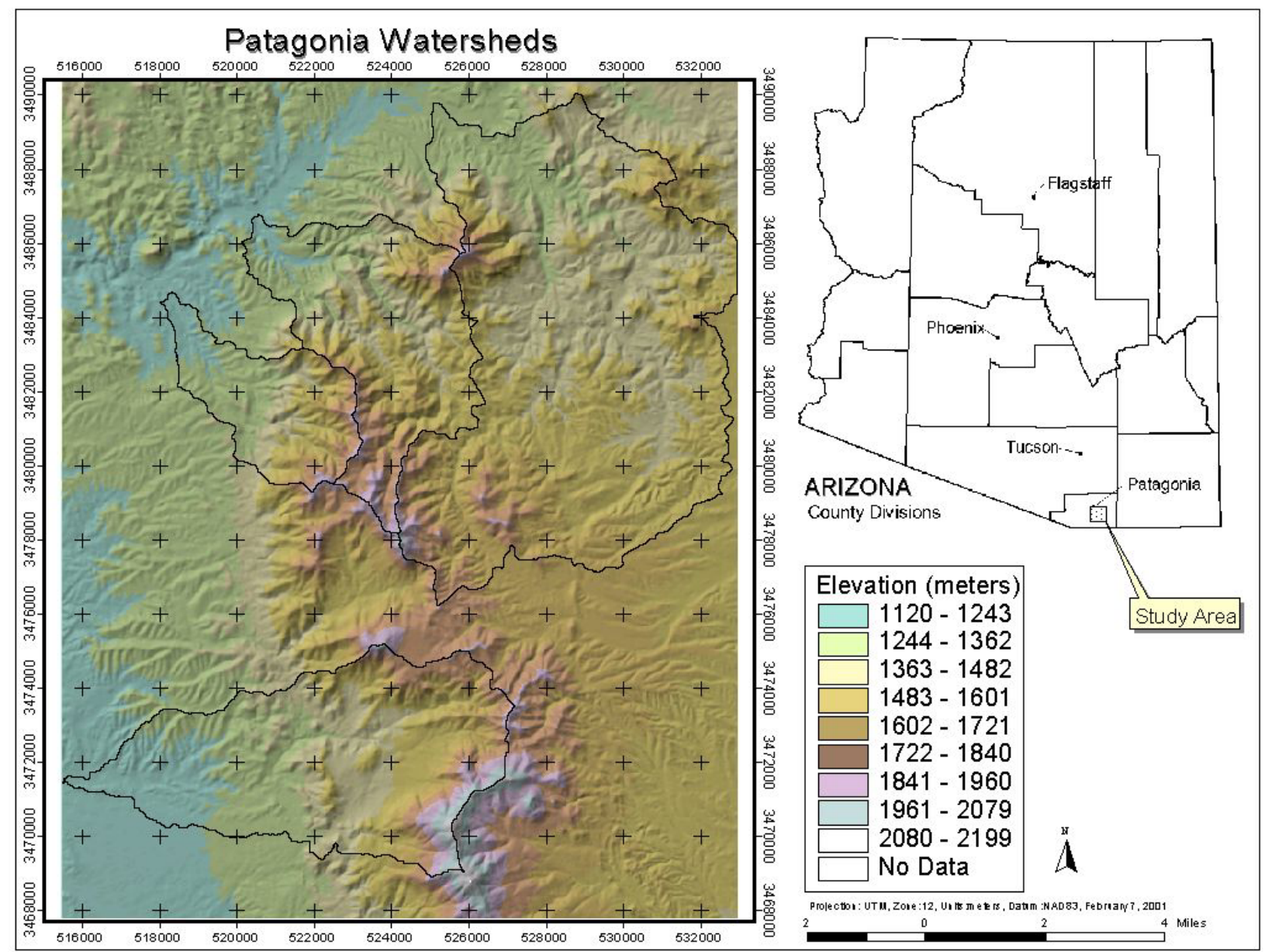

Figure 1: Index map showing the geographic extent of the Patagonia Mountains study area, with watersheds enclosed by black lines. 


\section{Description of Map Units}

The soil units' descriptions are modified from information published by the U.S. Department of Agriculture: Soil Conservation Service and Forest Service in cooperation with Arizona Agricultural Experiment Station (USDA, SCS \& FS, 1979).

Table 1: Symbols, Soils' association and USDA surface textures in the Patagonia soils map (U.S. Department of Agriculture: Soil Conservation Service and Forest Service in cooperation with Arizona Agricultural Experiment Station, 1979).

Ba Barkerville-Gaddes Complex -- Gravelly sandy loam and sandy clay loam

Bg Barkerville-Gaddes Association -- Gravelly sandy loam and sandy clay loam

Bh Bernadino-Hathaway Association - Gravelly clay loam and cobbly sandy loam

Ca Calciorthids-Haplargids Association -- Properties too variable to be estimated

$\mathrm{Cb}$ Canelo Gravelly Sandy Loam -- Gravelly, very gravelly, or cobbly sandy loam

Cg Caralampi Gravelly Sandy Loam -- Gravelly sandy loam and very gravelly sandy clay loam

Cm Casto Very Gravelly Sandy Loam -- Gravelly and very gravelly sandy clay loam

Co Chiricahua Cobbly Sandy Loam -- Cobbly or gravelly heavy clay loam or clay

Cr Chiricahua- Lampshire Association -- Cobbly or gravelly heavy clay loam or clay

Cs Comoro Sandy Loam -- Sandy loam and gravelly sandy loam

Ct Comoro Soils -- Sandy loam and gravelly sandy loam

Fr Faraway- Rock Outcrop Complex -- Very cobbly fine sandy loam

Ga Gaddes Very Gravelly Sandy Loam -- Gravelly sandy loam, sandy loam, sandy clay loam, gravelly clay, and cobbly sandy clay loam

Gb Grabe- Comoro Complex -- Loam and sandy loam

Ge Grabe Soils -- Loam and sandy loam

Gh Graham Soils -- Very cobbly clay loam and clay

Gu Guest Soils -- Clay, gravelly clay and gravelly clay loam

HO Water Bodies 
Ha Hathaway Gravelly Sandy Loam -- Gravelly sandy clay loam, gravelly and very gravelly sandy loam, and sandy loam

Lc Lampshire-Chiricahua Association -- Very cobbly loam

Lg Lampshire- Graham- Rock Outcrop Association -- Very cobbly loam

Lu Luzena Gravelly Loam, Deep Variant -- Gravelly clay loam and gravelly clay

Mg Martinez Gravelly Loam -- Loam or clay loam and clay

NA Not Available - Undefined soil type

Pm Pima Soils -- Clay loam

Rn Rock Outcrop- Lithic Haplustolls Association - Properties too variable to be estimated

So Sonoita Gravelly Sandy Loam -- Gravelly sandy loam

Th Torrifluvents and Haplustoils -- Properties too variable to be estimated

Tr Tortugas- Rock Outcrop Complex -- Very cobbly loam

Wg White House Gravelly Loam -- Gravelly loam, clay loam, and clay

Wh White House Cobbly Sandy Loam -- Gravelly loam, clay loam, and clay

Wn White House- Bonita Complex -- Gravelly loam, clay loam, and clay

Wo White House- Caralampi Complex -- Gravelly loam, clay loam, and clay

Wt White House- Hathaway Association -- Gravelly loam, clay loam, and clay

The data are also attributed by slope; the capital letters B, C, D, E, or F define the slope; if a soil type has no slope defined, it can be assumed to have nearly level slope or a considerable range of slope (U.S. Department of Agriculture: Soil Conservation Service and Forest Service in cooperation with Arizona Agricultural Experiment Station, 1979), as seen in table 2. 
Table 2: Slope attributes (U.S. Department of Agriculture: Soil Conservation Service and Forest Service in cooperation with Arizona Agricultural Experiment Station, 1979).

\begin{tabular}{|c|c|}
\hline Slope & Percent represented \\
\hline B & $0-5$ percent slopes \\
\hline C & $1-10$ percent slopes \\
\hline D & $0-20$ percent slopes \\
\hline E & $20-40$ percent slopes \\
\hline F & $1--60$ percent slopes \\
\hline
\end{tabular}

A final user defined attribute within the data is the eroded factor. If the attribute has the number 2, it was considered to be eroded at the time of the survey.

\section{Data Sources, Processing, and Accuracy}

The maps from which this dataset was made had not been rectified for distortion or registered to a coordinate system. A total of 15 maps (17" X 11") cover the study area. Each of these maps was scanned into tagged image file format (TIFF) using an 8-bit black and white drum scanner at 100 dpi (fig. 2). 


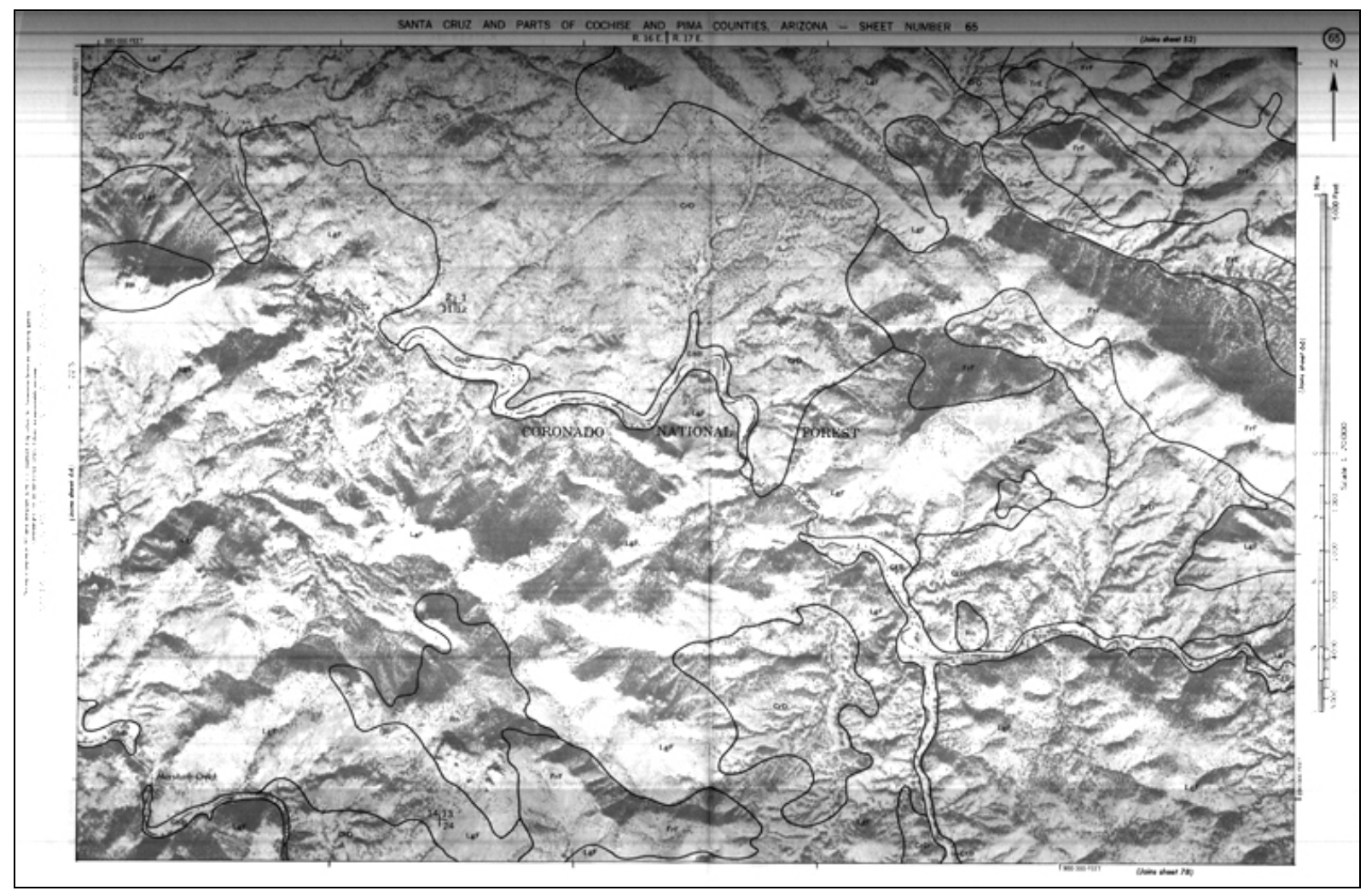

Figure 2: Soils Map: Santa Cruz and Parts of Cochise and Pima Counties, ArizonaSheet Number 65.

ERDAS IMAGINE was used to import the images and the white borders were removed through subset decollaring processes. Five CD-ROM's containing Digital Orthophoto Quarter Quads (DOQQ's) from the USGS were used to register and rectify the scanned soils maps. Polygons were then attributed according to the soil units on the map. Ground Control Points (GCP's) were established by matching known locations on the soil maps to the same location identified on a DOQQ, see figure 3. The aerial photos were taken some 30 years prior to processing into DOQQ's and buildings, trees, and waterways had changed considerably. Therefore, the easiest and most accurate objects to identify were roads and intersections of roads with other features. These appeared to have the same shape throughout time, although some forest roads were out of use or had been paved or widened. 


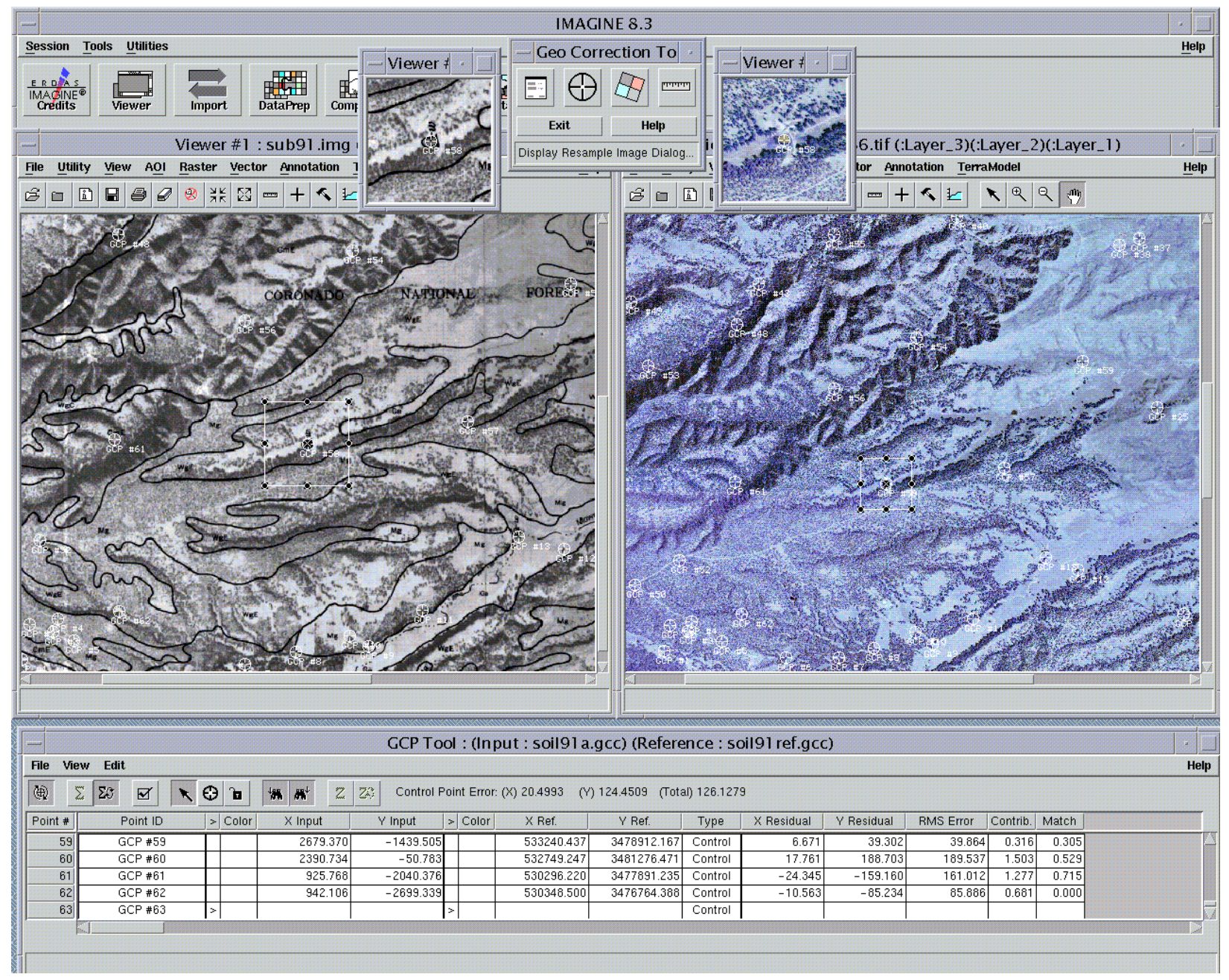

Figure 3: Picture of ERDAS IMAGINE georectification process.

A third-order polynomial transformation requires a minimum of $10 \mathrm{GCP}^{\prime} \mathrm{s}$ to be identified. However, the level of accuracy increases as more points are entered and widely distributed. The GCP prediction tool within ERDAS IMAGINE 8.4 uses the current transformation parameters to predict where the user will locate $\mathrm{GCP}^{\prime} \mathrm{s}$ from the work in progress to source data. This enables the user to determine when enough points have been entered to ensure that the transformation is accurate (ERDAS, 1997). An average of $80 \mathrm{GCP}^{\prime} \mathrm{s}$ were identified on each aerial photo and cross-referenced with the source data for this study.

The digital transformation was performed with the cubic convolution method of resampling to effectively associate the aerial photo with pinpoints to known coordinates and to adjust the map to accurate proportions. This sampling method is suggested for aerial photos in which the cell size is dramatically changed (ERDAS, 1997). 
This method transformed scanned soils maps into registered images. The cubic convolution method resamples using an algorithm that recognizes the data files of 16 pixels in a 4 by 4 window, and this creates the most accurate output when rectifying aerial photos (ERDAS, 1997). Error still exists despite the high number of GCP's used to control the transformation. The difficulty in accurately fitting images over mountainous terrain from aerial photos accounts for some of the error in rectification (Carson, 1993). Error exists in the DOQQ's due to possible error in input for the rectification that created them (digital elevation model (DEM), aerotriangulation control and methods, the photo source camera calibration, scanner calibration, and aerial photographs) and new error was introduced in the resampling process. However, the photos edge-matched positively and roads, rivers, trees and soil polygons merged together seamlessly when mosaiced to create a cohesive map. The raster geometric correction was successful for use in this project. The final .IMG file was converted and compressed within ARC/INFO to TIFF format and laid out onscreen with known vector coverages of digitized roads and rivers overlaid to check for accuracy and error. The rectified aerial photo is displayed in figure 4 , with a digital line coverage composed in TIGER, a GIS software, of Santa Cruz County. Error was determined to be within +/40 meters. These data are not meant to be used or displayed at any scale larger than 1:20,000. 


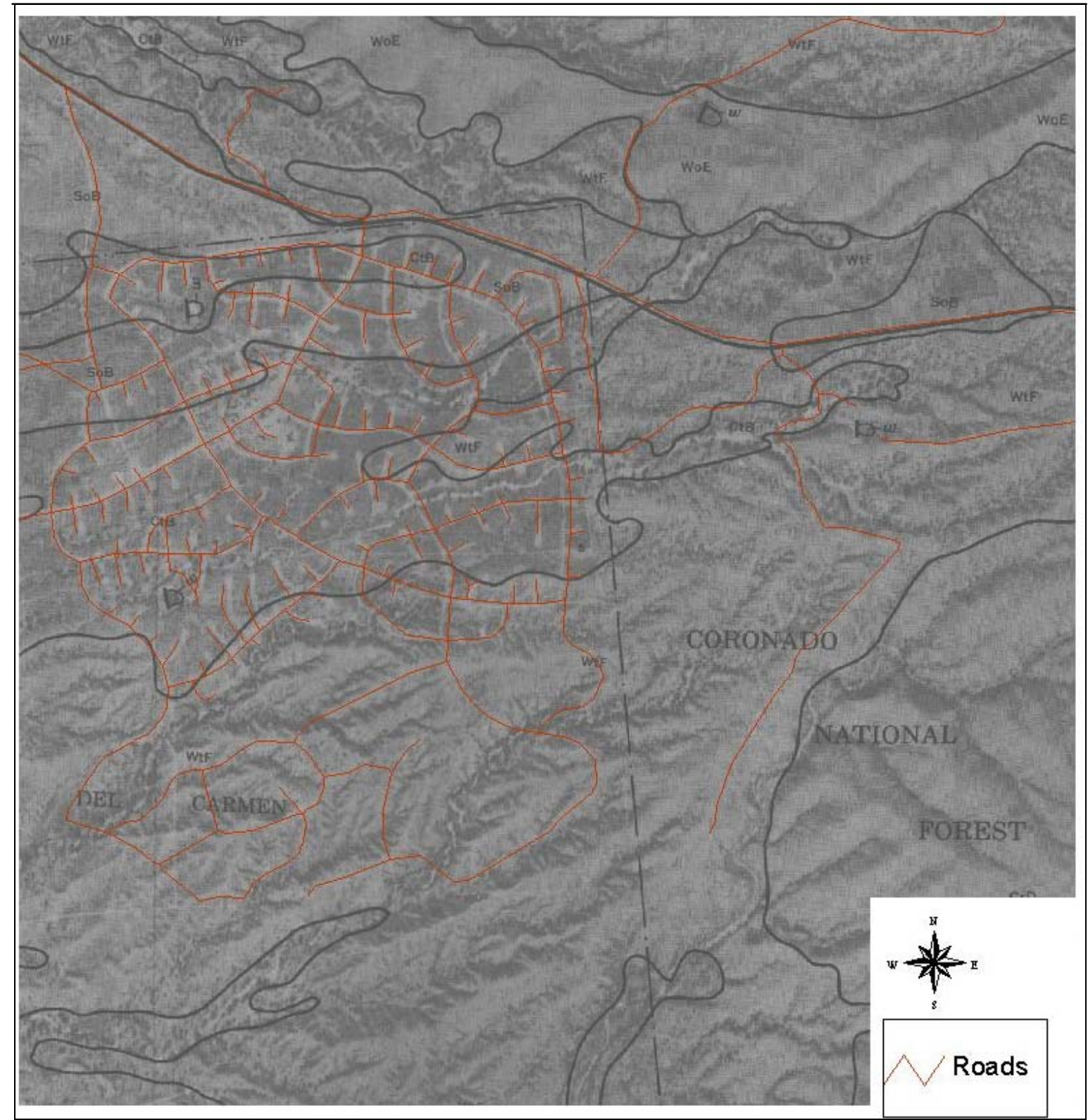

Figure 4: Campground area of aerial photo depicting error from overlain vector coverage of roads.

The soils data that had been inscribed on the aerial photos were then automated through the process of on-screen digitizing in ARCEDIT. The distance command identified acceptable tolerances, node snap to closest 100 meters and weed and grain tolerances to 15 meters. The user-friendly graphical user interface (GUI) called ARCTOOLS was employed for the initial digitizing. Topological errors were corrected manually using command line editing, and topology was built. 
User defined items were added to the newly digitized soil coverage feature attribute table to define the map unit descriptions: soil series, slope angle and previous erosion. Labels were created and attribution of the new soils coverage was completed using a form-based interface provided by ESRI within ARCEDIT. Four hundred and forty three polygons were attributed against the labeled polygons of the final aerial TIFF. A subset of the digitized polygons was made to correspond to the study area, which left 360 polygons. That set is displayed as a soil series map (fig. 5).

Thirty-two different soil types are represented in this area. The application of this type of digital map, with its newly formed relational database as stored in a GIS, creates a straightforward link amongst the soil polygon attributes (Maidment, 1993). The projection was defined according to the DOQQ that fostered it.

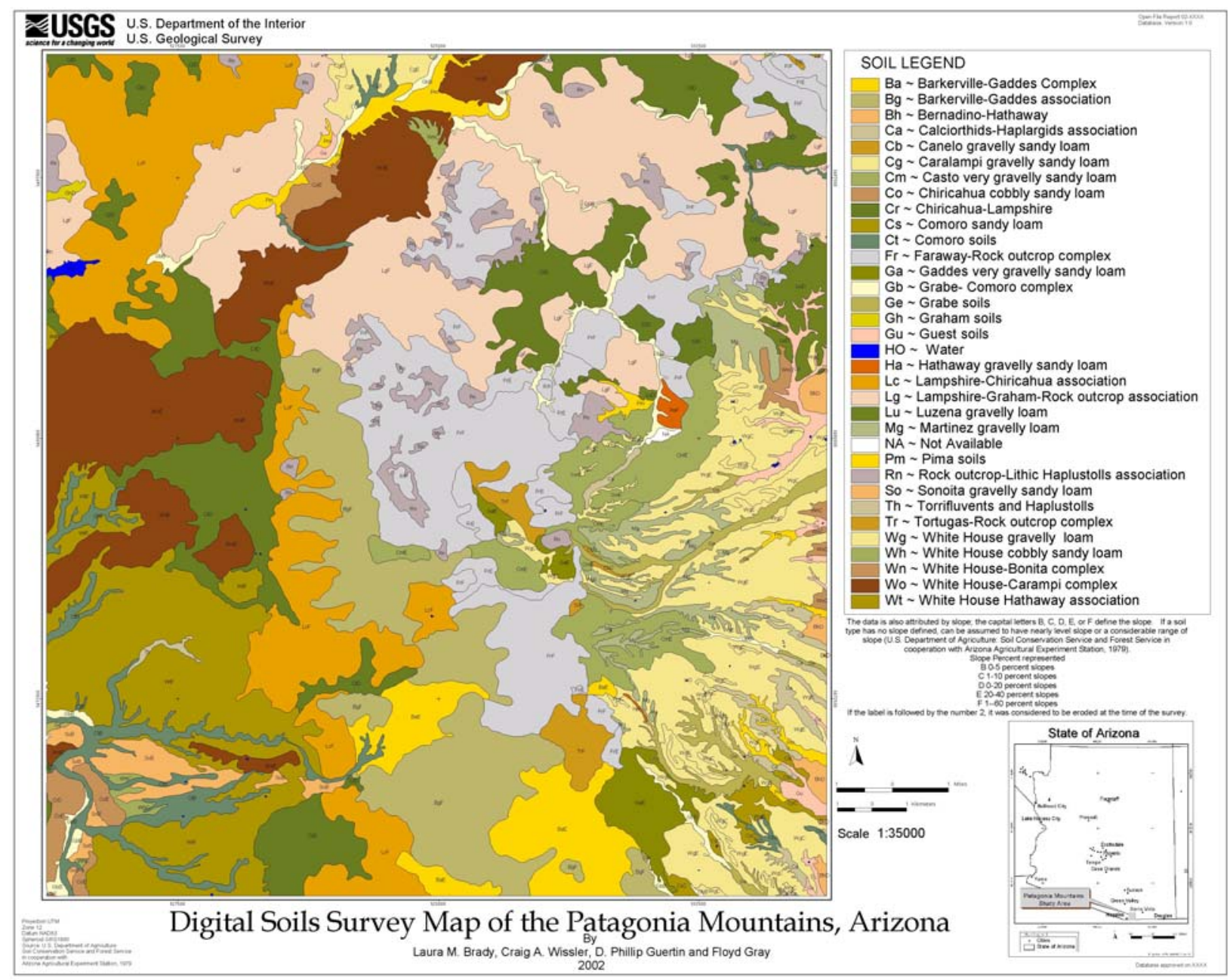

Figure 5: This digital soils survey map of the Patagonia Mountains, Arizona is available at a 40 X33 inch map size JPEG in this digital release. 


\section{GIS Documentation}

The digital soils data set of the Patagonia study area includes a polygon attribute table, SCS_Soil.PAT that contains relevant information. This table is described below.

\section{Polygonal Features}

The data coverage contains 361 polygon features, 1,015 arc features and 720 node features.

Table 3: Descriptions and data type of the user defined items identifying polygon features (symbol, slope and erodibility).

\begin{tabular}{|l|l|l|l|}
\hline \multicolumn{2}{|l|}{ scs_soil.pat } \\
\hline ITEM NAME & $\begin{array}{l}\text { ITEM } \\
\text { TYPE }\end{array}$ & $\begin{array}{l}\text { ITEM } \\
\text { LENGTH }\end{array}$ & ATTRIBUTE DESCRIPTION \\
\hline SOIL_SERIES & Character & 2 & $\begin{array}{l}\text { Symbol used to identify the soil series as defined } \\
\text { above, (table 1). }\end{array}$ \\
\hline SLOPE & Character & 2 & $\begin{array}{l}\text { Code given to show the slope (B, C, D, E, or F), } \\
\text { (table 2). }\end{array}$ \\
\hline IFERODED & Integer & 2 & $\begin{array}{l}\text { Boolean code used to identify if the area was } \\
\text { eroded at the time of survey. }\end{array}$ \\
\hline
\end{tabular}

\section{Obtaining Digital Data}

The complete digital data set is available in ArcInfo interchange file format with associated data files. These data and map images are maintained in a Universal Transverse Mercator (UTM) map projection:

Projection:

Zone:

Datum:

Units:
UTM

12

NAD83

meters 
To obtain copies of the digital data, do one of the following:

1. Download the digital files from the USGS public access World Wide Web site on the Internet: URL = http://geopubs.wr.usgs.gov/open-file/ofr02-324/

or

2. Anonymous FTP from geopubs.wr.usgs.gov, in the directory pub/open-file/ofr02-324

The Internet sites contain this report in PDF format, the digital soils map of the Patagonia study area in an ArcInfo exchange-format file (scs_soil.e00) and a JPEG file (scs_soil.jpg) of the automated map.

To manipulate these data in a geographic information system (GIS), you must have a GIS that is capable of importing ArcInfo interchange-format files.

\section{Obtaining Paper Maps}

Paper copies of the digital geologic map are not available from the USGS. However, with access to the Internet and access to a large-format color plotter that can interpret either image file (JPEG), or PDF (portable document format) files, a 1:35,000-scale paper copy of the map can be made, as follows:

1. Download the digital version of the map, scs_soil.jpg or scs_soil.pdf, from the USGS public access World Wide Web site on the Internet using the

URL = http://geopubs.wr.usgs.gov/open-file/ofr02-324/

or

2. Anonymous FTP the plot file, scs_soil.jpg or scs_soil.pdf, from:

geopubs.wr.usgs.gov, in the directory:

pub/open-file/ofr02-324

3. This file can be plotted by any large-format color plotter that can interpret JPEG or PDF files. The finished plot is about 30 inches by 42 inches.

Paper copies of the map can also be created by obtaining the digital file as described above and then plotting with GIS software. 


\section{References Cited}

Brady, L.M., 2000, GIS analysis of spatial variability of contaminated watershed components in a historically mined region, basin and range province, Southeast Arizona: Tucson, University of Arizona, Master thesis, $127 \mathrm{p}$.

Brady, L.M., Gray, F., Wissler, C.A., and Guertin, D.P., 2001, Spatial variability of sediment erosion processes using GIS analysis within watersheds in a historically mined region, Patagonia Mountains, Arizona: U.S. Geological Survey Open-File Report 01- 267.

Carson, Ward W., 1993. 'Monodigitizing', Make the Photograph match the Map": GIS World, v. 6, no. 10, p. 46-47.

ERDAS, Inc., 1997, ERDAS field guide (4th ed.): Atlanta, Georgia, p. 307- 342.

Fraser, R.H., 1999, SEDMOD: a GIS-based delivery model for diffuse source pollutants: New Haven, Conn., Yale University, Ph.D. dissertation, 99 p.

Gray, Floyd, Wirt, Laurie, Caruthers, Kerry, Gu, Ailiang, Velez, Carlos, Hirschberg, Douglas M., and Bolm, Karen, 2000, Transport and Fate of $\mathrm{Zn}$ and $\mathrm{Cu}$ rich, Low pH Water from Porphyry Copper and Related Deposits, Basin and Range Province, Southeastern Arizona; in Proceedings of the Fifth International Conference on Acid Rock Drainage, May 21-24, 2000, Denver, CO: (1), p. 411-430.

Maidment, David R., 1993. GIS and Hydrologic Modeling in Goodchild, Michael F., Parks, Bradley O. , Steyaert, Louis T., ed., 'Environmental Modeling with GIS.' Oxford University Press, NY, Oxford, p.147- 167.

U.S. Department of Agriculture: Soil Conservation Service and Forest Service in cooperation with Arizona Agricultural Experiment Station, 1979, Soil survey of Santa Cruz and parts of Cochise and Pima counties, Arizona: April 1979, 100 p.

Wischmeier, W.H., 1976, Use and misuse of the Universal Soil Loss Equation: Journal of Soil and Water Conservation, v. 31, no.1, p. 5-9.

Wischmeier, W.H., and Smith, D.D., 1978, Predicting rainfall erosion: a guide to conservation planning: U.S. Department of Agriculture Agronomy Handbook No. 537. 


\title{
Appendix A Metadata
}

Identification_Information:

\author{
Citation: \\ Citation_Information: \\ Originator: Laura Margaret Brady \\ Publication_Date: unpublished \\ Title: \\ COVERAGE SCS_SOIL -- Digital Soils Survey Map of the \\ Patagonia Mountains, Arizona \\ Edition: Version 1.5, March 12, 2002 \\ Geospatial_Data_Presentation_Form: map \\ Series_Information: \\ Series_Name: U.S. Geological Survey Open File Report \\ Issue_Identification: USGS OFR 02-324 \\ Publication_Information: \\ Publication_Place: Menlo Park, California \\ Publisher: U.S. Geological Survey \\ Online_Linkage: URL = http://geopubs.wr.usgs.gov/open-file/of02-324/ \\ Description:
}

\begin{abstract}
:
The ,"Soil Survey of Santa Cruz and Parts of Cochise and Pima Counties, Arizona", a product of the USDA's Soil Conservation Service and the Forest Service in cooperation with the Arizona Agricultural Experiment Station, released in 1979, was created according to the site conditions in 1971, when soil scientists identified soils types on aerial photographs. The scale at which these maps were published is 1:20,000.
\end{abstract}

These soil maps were automated for incorporation into the hydrologic modeling within a GIS. The aerial photos onto which the soils units were drawn had not been orthoganalized, and contained distortion. A total of 15 maps composed the study area. These maps were scanned into TIFF format using an 8-bit black and white drum scanner at $100 \mathrm{dpi}$. The images were imported into ERDAS IMAGINE and the white borders were removed through subset decollaring processes. Five CD-ROM's containing Digital Orthophoto Quarter Quads (DOQQ's) were used to register and rectify the scanned soils maps. Polygonal data was then attributed according to the datasets.

Purpose:

Beginning in March of 1997, the Preliminary Assessment 
of the Patagonia Mountains study area was undertaken. An integrated watershed analysis using Geographic Information Systems (GIS) based platform was undertaken to examine transport characteristics. The Universal Soil Loss Equation (USLE) and the Spatially Explicit Delivery MODel (SEDMOD) were chosen to assist in characterization of potential point and nonpoint source material yield within selected drainage systems.

This was done to provide information useful for defining areas of significant environmental impact and to shed some light on the most practical remediation strategies to be employed. Many studies have been conducted to determine different parameters, effects and contributions of human activity in the Patagonia and southern Santa Rita Mountains study area. Incorporation to a digital data model required acquisition of accurate geo-spatial digital soils data. This digital geospatial database is one of many being created by the U.S. Geological Survey as an ongoing effort to provide geologic information in a geographic information system (GIS) for use in spatial analysis.

Time_Period_of_Content:

Time_Period_Information:

Single_Date/Time:

Calendar_Date: 20011001

Currentness_Reference: required

Status:

Progress: In work

Maintenance_and_Update_Frequency: None Planned

Spatial_Domain:

Bounding_Coordinates:

West_Bounding_Coordinate: -110.85575013

East_Bounding_Coordinate: -110.61876161

North_Bounding_Coordinate: 31.55456386

South_Bounding_Coordinate: 31.33518703

Keywords:

Theme:

Theme_Keyword_Thesaurus: none

Theme_Keyword: Soils

Place:

Place_Keyword_Thesaurus: none

Place_Keyword: Southeastern Arizona

Place_Keyword: Patagonia, Arizona

Place_Keyword: USA

Place_Keyword: Arizona 
Access_Constraints: none

Use_Constraints:

Anyone who uses these data must cite USGS. These data are not to be used at scales greater than 1:20,000.

Point_of_Contact:

Contact_Information:

Contact_Person_Primary:

Contact_Person: Laura Margaret Brady

Contact_Organization: US Geological Survey, GD

Contact_Position: Geographer, GIS Specialist

Contact_Address:

Address_Type: mailing and physical address

Address: 520 N. Park Avenue, Suite 355

City: Tucson

State_or_Province: Arizona

Postal_Code: 85719

Country: USA

Contact_Voice_Telephone: (520) 670-5510

Contact_Facsimile_Telephone: (fax) (520) 670-5571

Contact_Electronic_Mail_Address: lmbrady@usgs.gov

Data_Set_Credit:

Coauthors helped to generate the final product map and ARCIFO coverage. Craig Wissler, professor at the University of Arizona, oversaw the automation and attribution of the actual data, while D.P. Guertin, also a professor at the University of Arizona, helped in assessing the final product and its further applications. Floyd Gray, geologist at the USGS, hired the work to be done as part of a 5-year project investigation of the fate and transport of minerals in the Patagonia Mountains in association with abandoned mine locations.

Karen Bolm, also of the USGS, helped tremendously in the review of digital and manuscript data.

Native_Data_Set_Environment:

SunOS, 5.6, sun4u UNIX

ARCINFO version 7.2.1

Data_Quality_Information:

Attribute_Accuracy:

Attribute_Accuracy_Report:

The final file was converted and compressed within ARCINFO to TIFF format and laid out onscreen with known vector coverages of digitized roads and rivers overlaid to check for accuracy and error. The most useful was the road coverage downloaded the AZGENREF library, which 
identified error to be within $+/-40$ meters. This digital

database is not meant to be used or displayed at any

scale larger than 1:20,000.

Logical_Consistency_Report:

Polygon topology present.

All polygons are closed.

Completeness_Report:

Only the maps that covered the study area of interest

were digitized.

Positional_Accuracy:

Horizontal_Positional_Accuracy:

Horizontal_Positional_Accuracy_Report: Identified error to be within +/- 40 meters

Lineage:

Source_Information:

Source_Citation:

Citation_Information:

Originator:

U.S. Department of Agriculture: Soil Conservation Service

and Forest Service in cooperation with Arizona

Agricultural Experiment Station, 1979, Soil survey of

Santa Cruz and parts of Cochise and Pima counties,

Arizona: April 1979, 100 p.

Publication_Date: 1979

Title:

Soil survey of Santa Cruz and parts of Cochise and Pima

counties, Arizona

Geospatial_Data_Presentation_Form:

hardcopy aerial photos with polygonal soil attributes

traced on

Publication_Information:

Publication_Place: Washington, D.C.

Publisher: U.S. Government Printing Office

Source_Scale_Denominator: 20,000

Source_Time_Period_of_Content:

Time_Period_Information:

Single_Date/Time:

Calendar_Date:

Range_of_Dates/Times

Beginning_Date 1967

Ending_Date 1970

Source_Contribution: soils map

Process_Step:

Process_Description:

Known points were identified on the aerial photo and 
matched to points on the DOQQ's, these were referred to as Ground Control Points (GCP's). This was the most time consuming portion of this project as the aerial photos were taken some 30 years prior to the DOQQ's and buildings, trees, and waterways had changed considerably. The easiest and most accurate objects to identify were roads and intersections of roads with other features. These appeared to have the same shape throughout time, although some forest roads are out of use, or have been paved or widened. A 3rd order polynomial transformation requires a minimum of $10 \mathrm{GCP}^{\prime}$ s to be identified. However, the level of accuracy increases as more points are entered and widely distributed. The GCP prediction tool within ERDAS IMAGINE uses the current transformation parameters to guess where the user will locate GCP's from the work in progress to source data, this enables the user to determine when enough points have been entered to ensure that the transformation is accurate. An average of $80 \mathrm{GCP}^{\prime} \mathrm{s}$ were identified on each aerial photo and cross-referenced with the source data for this study. The cubic convolution method of resampling was performed to effectively pierce the aerial photo with pinpoints to known real time coordinates and stretch or fold the picture to accurate proportions. This sampling method is suggested for aerial photos in which the cell size is dramatically changed. This transformed the image of an abstract piece of paper into an accurate representation of real time and space with registered known coordinates. The cubic convolution method resamples using an algorithm which recognizes the data files of 16 pixels in a 4 by 4 window, and this creates the most accurate output when ortho-rectifying aerial photos. Error still exists despite the high number of GCP'sused to control the transformation. It is difficult to accurately fit images over mountainous terrain from aerial photos. Error existed in the DOQQ,' and new error was introduced in the resampling process. However, the photos edge-matched positively and roads, rivers, trees and soil polygons merged together seamlessly when mosaiced to create the big picture. The raster geometric correction was successful for use in this project.

Process_Date: 2000

Process_Step:

Process_Description: Fifth draft of metadata created by lmbrady using FGDCMETA.AML ver. 1.2 05/14/98 on ARC/INFO data set /bdr2/lmbrady/scs_soil

Process_Date: 20020312 
Spatial_Data_Organization_Information:

Direct_Spatial_Reference_Method:Vector

Point_and_Vector_Object_Information:

SDTS_Terms_Description:

SDTS_Point_and_Vector_Object_Type: Point

Point_and_Vector_Object_Count: 360

SDTS_Point_and_Vector_Object_Type: String

Point_and_Vector_Object_Count: 1015

SDTS_Point_and_Vector_Object_Type: GT-polygon composed of chains

Point_and_Vector_Object_Count: 361

Spatial_Reference_Information:

Horizontal_Coordinate_System_Definition:

Planar:

Grid_Coordinate_System:

Grid_Coordinate_System_Name: Universal Transverse Mercator

Universal_Transverse_Mercator:

UTM_Zone_Number: 12

Transverse_Mercator:

Scale_Factor_at_Central_Meridian: implied

Longitude_of_Central_Meridian: implied

Latitude_of_Projection_Origin: implied

False_Easting: implied

False_Northing: implied

Planar_Coordinate_Information:

Planar_Coordinate_Encoding_Method: coordinate pair

Coordinate_Representation:

Abscissa_Resolution: 2.498300075531

Ordinate_Resolution: 2.498300075531

Planar_Distance_Units: Meters

Geodetic_Model:

Horizontal_Datum_Name: North American Datum of 1983

Ellipsoid_Name: GRS1980

Semi-major_Axis: 6378206.4

Denominator_of_Flattening_Ratio: 294.98

Entity_and_Attribute_Information:

Overview_Description:

Entity_and_Attribute_Overview:

Explanations of the user defined items listed below can be found in OFR text:

SCS_SOIL83.PAT:

COLUMN ITEM NAME WIDTH OUTPUT TYPE N.DEC ALT. NAME

$\begin{array}{llccccc}1 & \text { AREA } & 8 & 18 & \mathrm{~F} & 5 & \\ 9 & \text { PERIMETER } & & 8 & 18 & \mathrm{~F} & 5 \\ 17 & \text { SCS_SOIL83\# } & 4 & 5 & \mathrm{~B} & - \\ 21 & \text { SCS_SOIL83-ID } & 4 & 5 & \mathrm{~B} & - \\ 25 & \text { SOIL_SERIES } & 2 & 2 & \mathrm{C} & -\end{array}$


27 SLOPE

29 IFERODED
22 C -

22 I -

SCS_SOIL83.AAT:

COLUMN ITEM NAME WIDTH OUTPUT TYPE N.DEC ALT. NAME

\begin{tabular}{llccccc}
1 & FNODE\# & 4 & 5 & B & - \\
5 & TNODE\# & 4 & 5 & \multicolumn{2}{c}{ B } & - \\
9 & LPOLY\# & 4 & 5 & \multicolumn{1}{c}{ B } & - \\
13 & RPOLY\# & 4 & 5 & B & - \\
17 & LENGTH & 8 & 18 & F & 5 \\
25 & SCS_SOIL83\# & 4 & 5 & B & - \\
29 & SCS_SOIL83-ID & & 4 & 5 & B & -
\end{tabular}

Entity_and_Attribute_Detail_Citation: none

Distribution_Information:

Distribution_Liability:

The U.S. Geological Survey (USGS) provides these geographic data "as is." The USGS makes no guarantee or warranty concerning the accuracy of information contained in the geographic data. The USGS further makes no warranties, either expressed or implied, as to any other matter whatsoever, including, but without limitation to, the condition of the product of its fitness for any particular purpose. The burden for determining fitness for use lies entirely with the user. Although these data have been processed successfully on computers with USGS, no warranty, expressed or implied, is made by the USGS regarding the use of these data on any other system, nor does the fact of distribution constitute or imply such warranty.

In no event shall the USGS have any liability whatsoever for payment of any consequential, incidental, indirect, special, or tort damages of any kind, including, but not limited to, any loss of profits arising out of use of or reliance on the geographical data or arising out of the delivery, installation operation, or support by USGS.

The digital geologic map GIS of the Patagonia Mountains area in Arizona is not meant to be used or displayed at any scale larger than 1:20,000 (for example, 1:12,000).

Metadata_Reference_Information:

Metadata_Date: 20020312

Metadata_Contact:

Contact_Information:

Contact_Organization_Primary:

Contact_Organization: USGS

Contact_Person: Laura Margaret Brady

Contact_Position: Geographer/ GIS Specialist

Contact_Address: 
Address_Type: mailing and physical address

Address: 520 N. Park Ave., Suite \#355

City: Tucson

State_or_Province: AZ

Postal_Code: 85719

Country: USA

Contact_Voice_Telephone: (520) 670-5510

Contact_Facsimile_Telephone: (fax)(520) 670-5571

Contact_Electronic_Mail_Address: Imbrady@usgs.gov

Metadata_Standard_Name: FGDC Content Standards for Digital Geospatial Metadata

Metadata_Standard_Version: Version of June 8, 1994

Metadata_Access_Constraints: none

Metadata_Use_Constraints: none 